Miroslav Jurasek,

Ph.D., University of Finance and Administration, Prague, Czech Republic

(iD) ORCID ID orcid.org/0000-0002-5381-8936,

email: miroslav.jurasek@outlook.com

Tomislav Potocky,

Ph.D., University of Finance and Administration, Prague, Czech Republic

Correspondence author: miroslav.jurasek@outlook.com

\title{
MANAGEMENT OF INNOVATIONS IN CROSS-CULTURAL COMMUNICATION WITHIN AN ORGANIZATION
}

\begin{abstract}
This paper summarizes the arguments and counterarguments within the discussion on the issue of cultural intelligence, bilingualism, and the relationship between language proficiency and cultural intelligence. The primary purpose of the research is to explore the relationship between bilingualism (or high language proficiency in two languages) and cultural intelligence. The systematization of literary sources and approaches for solving the problem indicates that a significant link between these constructs could be expected. The relevance of the decision of this scientific problem is that this relationship has not yet been the subject of any previous research. Investigation of the paper topic is carried out in the following logical sequence: a thorough look into a conceptual and theoretical framework of cultural intelligence, bilingualism and the link between cultural intelligence and language proficiency; in the second part of the paper two hypotheses are developed on the base of previous research, and the corresponding methodology is described. The theoretical model of the explored relationship is tested using the SmartPLS-SEM 3 program. The objects of the survey are 243 undergraduate students studying in the English study program at the University of Finance and Administration in the Czech Republic. The research empirically confirms and theoretically proves that there is a positive correlation between the level of foreign (non-native) language proficiency and cultural intelligence score. Language competence predicates the overall rating for CQ. The metacognitive and motivational factors of $C Q$ play a substantial role within the framework of this relationship. On the other hand, data do not confirm a statistically significant difference between the group of bilingual and monolingual respondents. The results of the research can be useful for those who manage people across cultures and prepare students for working abroad or in international teams such as language teachers at universities.
\end{abstract}

Keywords: cultural intelligence, language proficiency, bilingualism, biculturalism, cultural frame switching, PLSSEM, intercultural effectiveness

Introduction. Management experts agree that workers who come into contact with a culturally diversified environment cannot do without intercultural competences (Andresen and Bergdolt, 2017). According to Petru, Tomaskova, and Kroslakova (2019), the increasingly intensive process of globalization requires new approaches to management, quality and innovation, marketing communication, increasing expertise, and finding ways of being successful in the domestic and international markets. Employees are expected to have skills and abilities which will enable them to successfully adapt during interpersonal contact in new cultural (not only work) environments. Diverse customs, values and norms distinguish this.

One factor of intercultural effectiveness can communicate in a foreign language. It helps to create shared meaning, to make a good impression, to improve performance, and contributes to smoother social interactions increasing a person's enjoyment and interest in dealing across cultures (Earley et al., 2006; Hofstede et al., 2010). Another factor that may influence the adaptability of individuals to unusual situations (and therefore, also their efficiency) is intelligence, especially the components of emotional and social intelligence (Crowne, 2009). Their ability to be successfully active in culturally diversified environments is

Cite as: Jurasek, M., \& Potocky, T. (2020). Management of Innovations in Cross-Cultural Communication within an Organization. Marketing and Management of Innovations, 2, 108-121. http://doi.org/10.21272/mmi.2020.2-08 
quantified more comprehensively by the concept of cultural intelligence (CQ) (Gabel-Shemueli, Westman, Chen, and Bahamonde, 2019), which has been created in direct connection with an analysis of the specific characteristics and tendencies of globalization and the transnational economy (Purtranto et al., 2018).

It is possible to use cultural intelligence to measure an individual's disposition and ability to function effectively in a new cultural environment, i.e., said individual's intercultural competence. If the initial postulate of the theory of linguistic relativity is accepted, our understanding and vision of the world and its cultural diversity depends, according to the so-called Sapir-Whorf hypothesis, on the use of the appropriate language (Pavlenko, 2006). Language and culture, therefore, constitute two indivisible concepts that form two sides of the same coin (Chen et al., 2014). It is possible to influence social perception, thought, and behavior using language, which is especially apparent in the case of bilingual individuals. It has been proven within this context (L. Cohen and Kassis-Henderson, 2017) that linguistic and cultural diversity has a positive effect on the cohesiveness and effectiveness of teamwork within specific organizational structures.

New evidence (Boroditsky, 2011) suggests that the relationship between culture and language is bidirectional. Core elements of culture such as belief systems and values-influence language, but these elements might also be influenced by language. Several studies (see, for example, Shannon and Begley, 2008) have dealt with the relationship between cultural intelligence and language competence; it has been confirmed that the level of language proficiency has a statistically significant influence on CQ. Also, it holds that a person who is better able to communicate (or is a more advanced user of the language of the host country) is better able to adapt to a new cultural environment and is therefore also more efficient at work (Jyoti and Kour, 2017).

If the level of language proficiency is a predictor of cultural intelligence, it can be justifiably supposed that a high level of cultural intelligence will distinguish bilingual individuals who can speak two languages perfectly and combine two different cultural identities within themselves via the mechanism of cultural frame switching (Luna et al., 2008). Within this context, the question is raised whether bilingualism (no matter whether this is achieved through natural development from birth or through one's efforts and studies of foreign languages) transforms an individual into a sensitive expert on cultural differentness and automatically predisposes such an individual for success (from his or her work, adaptation, life satisfaction, etc.) in an unknown cultural environment which is not related to the area of said individual's linguistic dominance.

As far as the authors of the study are aware, the ability (measured in this study using the concept of cultural intelligence) of bicultural, bilingual individuals to succeed in a new cultural environment has yet to have been researched. This study, therefore, represents a significant contribution to the research into the phenomenon of bilingualism (see also, for example, Pavlenko, 2006; van Oudenhoven and BenetMartínez, 2015; Veltkamp et al., 2013). By combining both concepts (bilingualism and CQ) the literature about $C Q$ has also been enriched, because it will be possible to demonstrate in this way that $C Q$ is relevant to specific types of (culturally diverse) situations as one particular general ability and that it does not only apply to one particular culture (Ang and Van Dyne, 2015).

This study suggests that a relationship exists between language proficiency (or achieved linguistic level) and $\mathrm{CQ}(\mathrm{H} 1)$; at the same time, it is also expected that there will be a significant difference in the value of overall cultural intelligence $(\mathrm{H} 2)$ between groups of bilingual individuals (displaying a high level of linguistic advancement) and monolingual individuals characterized by a lower level of linguistic ability.

The article has the following structure. Chapter 1 (Literature review) sets out the conceptual and theoretical starting points for this study. The existing research into $C Q$ and the role of languages in international trade with an emphasis on bilingualism are briefly presented. There is a brief discussion of the CFS mechanism (cultural frame switching), using which the biculturalism of a bilingual individual and the relationship between languages and $C Q$ are activated. Chapter 2 (Methodology and research 
methods) lists several studies that have researched the relationship between language proficiency and $\mathrm{CQ}$; two hypotheses have been formulated for this relationship. The used methods have also been described. Chapter 3 (Conclusions) sets out and discusses the results. The limitations of the study and proposals for further research are stated in conclusion.

Literature Review. Cultural intelligence, hereafter, simply referred to as $C Q$, is usually defined as the ability to function in a culturally diverse environment (Ang and Van Dyne, 2015) adequately. Cultural diversity is understood to mean differentness not only in the sense of national cultural values but also from subcultures, professions, age, employment, and religion. The conceptualization of CQ has been most highly elaborated at the level of the individual and, to a lesser extent, at the level of work teams and corporate organizations (Van Dyne et al., 2012).

Earley and Ang (2003) based their model of $C Q$, which has subsequently been used for a wide range of other research, on four dimensions: 1) cognitive - operating with general cultural knowledge which the individual uses in order to be able to comprehend a given new environment; 2) metacognitive - relating to the mental processes which lead to the comprehension of cultural knowledge; 3) behavioural - connecting the ability to behave appropriately in a new cultural environment (this includes a wide range of expressions of a verbal nature (adapting one's tone of voice, gesticulation and body language and so on) and a nonverbal nature (proxemics, eye contact and so on, Presbitero and Attar, 2018)) and 4) motivational reflecting the interest of the individual in foreign cultures and his or her belief in his or her own ability to successfully overcome any acculturation difficulties; energy and attention are focused on getting to know new cultures and the willingness to make contact with the members of unknown cultures is maintained on the basis of this dimension despite the difficulties (of a cultural nature) which this may present.

Other researchers have also offered a similar yet different conceptualization of $C Q$ (Thomas et al. 2008). In their interpretation, $C Q$ is considered to be a construct of a higher order, which is established using the interaction of lower-order factors. This contract is divided into three dimensions: 1) cultural knowledge - the individual has information about the culture (about the values and beliefs she had by a certain group), about how cultures differ from one another, about how culture influences the behavior of individuals and about the fundamental principles of intercultural behavior; 2) cultural metacognition - the individual monitors and regulates the cognitive processes to achieve his or her objectives within the framework of his or her cultural experience and strategy; 3 ) intercultural skills - the individual has a specific set of general cultural expertise and a register of behavior enabling said individual to collect information, develop relationships and adapt in a different cultural environment.

Unlike quantitative studies, qualitative research relies on a more full span of definitions and structures of CQ. For example, Oliver, de Botton, Soler, and Merrill (2011) viewed CQ as the ability to interpret one's situation. For others (Capatina et al., 2011), CQ represents «the ability to be intelligible to one's environs and to establish constructive partnerships in different cultural environments.» Several qualitative studies have dealt with the dimensions and structure of CQ (Kaufman and Hwang, 2015), the dissimilarity of CQ in comparison with other constructs (Schreuders-van den Bergh and Du Plessis, 2016) and CQ at a company level (Capatina et al., 2011). International trade and education are the most frequent research contexts for $\mathrm{CQ}$.

Bilingualism concerns the phenomenon whereby a speaker fluently transitions from one linguistic code to another when coming into contact with a foreigner; within the context of transnational migration, this involves the alternation of languages during contact with members of one's linguistic community and the members of the so-called adopting society. At the same time, Chen and Bond (2010) have specified a subgroup of so-called coordinated bilinguals who learn a foreign language within the framework of the education system, but use their mother tongue in their community and family. For Pavlenko (2006), the central phenomenon of bilingualism involves the use of two languages daily regardless of the level of language proficiency. This understanding of bilingualism is reflected in the line of research that is relevant 
for this study. However, it is not differentiated between how these languages (or one non-native language) are learned: either «naturally» (practically from birth) through regular contact with individuals who come from two different linguistic environments or based on targeted (institutional) language education.

It has been proven that bilingualism has a significant influence on speech and cognitive function (Bialystok et al., 2009). Learning a language does involve not only linguistic codes but also a particular way of thinking, a style, and norms of behavior and the expression of feelings (Boski and Youssef, 2012). Bilingual individuals perceive the world differently than purely monolingual individuals: when transitioning from one linguistic code to another, their way of thinking and forms of verbal and non-verbal behavior also change; this split identity is a source of satisfaction or some and frustration for others.

By actively using a language, a person becomes a member of a specific culturally defined group and a participant in social interactions at a wide range of levels. Language and values represent mutually linked cultural fundaments. Communication is the bearer of a specific cultural DNA and, at the same time, a transmitter of social practices that are activated by specific situational cues. Bilingual and bicultural individuals usually respond to the expressions of a particular culture in a manner that is typical for the behavior of its members (Pavlenko, 2006). Language is the trigger that activates a pattern of behavior and attitudes associated with the given culture (Grosjean, 2015). This effect has been explained in the accommodation theory (S. X. Chen, 2015).

A foreigner acquires the prerequisites for successful adaptation in a new cultural environment using his or her linguistic confidence and cultural awareness. As the given individual learns the specific language to a higher level, he or she gradually forms a new cultural identity and becomes bicultural (Kmiotek, 2017). At the same time, the individual's intercultural competence (mainly that based on personality), in other words, the ability of the individual to interact with people from different cultures effectively, also develops. The development of intercultural competence is an adequate strategy for life in a bicultural (or multicultural) environment (van Oudenhoven and Benet-Martínez, 2015). Biculturalism implies several positively connoted effects: increased creativity, successful psychological and socio-cultural adaptation to a new cultural environment, and, last but not least, a higher chance at work success (S. X. Chen, Benet-Martnez, and Harris Bond, 2008).

When transitioning from one cultural setting to another, bilingual individuals apply the accommodation mechanism of so-called cultural frame switching, hereafter simply referred to as CFS, which is based on the phenomenon of double consciousness. CFS assists bicultural individuals in performing their diverse social roles. The switching of cultural frames is more straightforward, the closer they are to a switched cultural identity (van Oudenhoven and Benet-Martínez, 2015). Switching between two languages in bilingual individuals who have internally identified with the cultural scope of both linguistic dominants changes their behavior and subjective experiences (Chen and Bond, 2010; Veltkamp et al., 2013). The advance knowledge of two languages (one mother tongue and a second language learned to the level of a native speaker) affects the formation of the bicultural identity; it can, however, also formulate the inverse relationship: the preference of certain cultural values may significantly reinforce the motivation to acquire advanced competence in a foreign language. In other words, if a person acknowledges certain cultural values, he or she is internally motivated; therefore, he or she is willing to expend significant efforts to continually improve and communicate in the language in which the members of the given cultural group speak (Kmiotek 2017).

As far as the authors are aware, this study is the first to concern itself with the relationship between $\mathrm{CQ}$ and bilingualism, i.e., the knowledge of two languages at the level of native speakers. Researchers in the field of international trade have understandably paid significant attention to the study of language proficiency (Brannen et al., 2017), but not about the development of specific abilities such as CQ, for example (Ott and Michailova, 2017).

Based on the previous research, it is possible to state that linguistic abilities are a critical factor for the 
development of $C Q$; specifically, the number of languages spoken at a very advanced level positively predicates the cognitive component of CQ (Eisenberg et al., 2013; Huff, 2013; Shannon and Begley, 2008) and $C Q$ in general (Shannon and Begley, 2008). By contrast, a negative correlation has been found between the motivational and behavioral components of $C Q$ and the advanced level of linguistic knowledge; also, it has been discovered that linguistic knowledge plays a more significant role for those who have shown a lower score in the metacognitive and cognitive components $C Q$ about an adjustment in a new cultural environment (Huff, 2013). The results of these studies have shown that linguistic faculties at a very high level are especially crucial for the cognitive component of $\mathrm{CQ}$ (associated with acquiring cultural knowledge and information during intercultural meetings), but this does not apply to all parts of $C Q$ (behavioral, motivational); in this case, advance linguistic knowledge tends to have a negative influence on the development of $\mathrm{CQ}$.

This theoretical finding has practical implications in tertiary education: international students receive the most significant benefit from the development of their intercultural competence (measured through the development of $C Q$ ), if they do not only study the selected courses in English (i.e., the lingua franca for global tertiary education) during their one or two-semester stay but also in the official language of their host country (Barner-Rasmussen et al., 2014; Ott and Michailova, 2017). This experience of studying abroad is considered to be a competitive advantage in the job market. Several companies and organizations value culturally competent managers as sources of strategic capital (Jyoti and Kour, 2017).

Methodology and research methods. The objective of the study is to examine cultural intelligence in bilingual individuals. Based on earlier research (A. S. Chen et al., 2011; Huff, 2013; Jyoti and Kour, 2017), it has been determined that a relationship exists between language proficiency expressed by the level of linguistic ability in the best non-native language and $C Q$.

$\mathrm{H} 1$ : A high level of language proficiency positively correlates with cultural intelligence.

The relationship contained in $\mathrm{H} 1$ has been newly examined below. Language is considered to be part of the culture. Switching from one word to another also changes the mode of the cultural setting and behavior. For example, an individual who fluently speaks the languages spoken both at a company's headquarters and at its international branches functions as a kind of «bridge» between the cultures of both countries (Barner-Rasmussen et al., 2014; Ott and Michailova, 2017). Bilingual individuals are adept at using two languages fluently, and they can be approached as individuals who use not only their mother tongue but also one foreign language for problem-free regular and expert communication. As such, it can be expected that the $C Q$ will differ in the groups with advanced and less advanced language proficiency. For this study, the respondents were divided into two groups: monolingual (= those who evaluated their language proficiency as being worse) and bilingual (with a high self-evaluation of their language proficiency). Therefore, the hypothesis $\mathrm{H} 2$ has been formulated in this way:

$\mathrm{H} 2$ : The average $\mathrm{CQ}$ value will significantly differ between the monolingual and bilingual groups.

The proposed hypotheses were tested using the PLS-SEM program. Hair Jr, Hult, Ringle, and Sarstedt (2016) have concluded that PLS-SEM constitutes a suitable analytical tool for research, provided the research objective involves the creation of a new theory, the structural model is comprehensive, and the data is not distributed normally. PLS-SEM also works in the testing of a new anticipated relationship and on a relatively small sample of respondents (other techniques such as CB-SEM are more confirmationfocused and require a much higher number of respondents for the test). The PLS-SEM was chosen because this involves an explorative study based on a new relationship in which $C Q$ (or its dimensions) is a predicate (output) and not a predictor. The method is recommended for a relatively low sample of respondents.

The conceptual and structural models were investigated using the SmartPLS 3 software (Hensler et al., 2015). The data analysis was undertaken using the PLS algorithm, the bootstrapping and blindfolding techniques, and MGA-PLS (multiple group analysis). The results of the reflective model were compared 
with the recommended criteria for the reliability and validity measurement model (Hair Jr et al., 2016): composite reliability $(C R) \geq 0.70$ (internal consistency), factor loading $\geq 0.70$ (reliability indicator), AVE > 0.50 (convergent validity), the square of AVE for each construct > any vertical or horizontal correlation (the Fornell-Larcker criterion - discriminant validity), HTMT < 0.90 and the HTMT indicators do not include 1 (discriminant validity) in their reliability interval. The RMS_theta, SRMR and NFI values have shown data conformity with the model in PLS-SEM. According to the designated criteria, the RMS_theta values should be less than 0.12, the SRMR values less than 0.08 and the NFI values between the values of 0 and 1 (the closer to zero, the better the fit) (Henseler et al., 2014).

MGA-PLS (multiple group analysis) was used when evaluating the second hypothesis. This analysis enables the designation of statistically significant differences in specific estimates of the parameters (external weights, external loading, and «pathway» coefficients) for pre-defined groups. SmartPLS provides outputs from three different approaches, which are based on the results of bootstrapping for each group. The respondents were divided into two groups based on the average score from the self-evaluation of their language proficiency: bilingual (4.22 and more) and monolingual (4.21 and less); then, it was examined whether any statistically significant difference in the overall $C Q$ score existed between these groups.

In this study, cultural intelligence (CQ) is measured based on the CQS (Cultural Intelligence Scale) self-evaluation questionnaire, which was created by Ang et al. 2007(a). This questionnaire has been developed for the business sphere. Still, for all that, the measurement of the CQ concept is also valid in other fields and sectors, including the area of schools and education (Collins et al., 2016). This involves the only CQ measurement (Van Dyne et al., 2016), which has undergone strict testing with the use of the entire range of source data; the structural validity of this measurement has been proven in many empirical studies. Cronbach's alpha (correlation) expresses the reliability of the individual entries measuring a given construct. Regarding the measurement of $C Q$ and this study, Cronbach's alpha is equal to 0.917 . This satisfactorily high value means that the $C Q$ measurement is reliable, and the data distribution is normal.

The respondents evaluated their language proficiency (in listening, writing, speaking, and reading), i.e., the ability of the users of foreign languages to demonstrate these for aspects of language proficiency in everyday situations, using a questionnaire borrowed from Luna, Ringberg and A Peracchio (2008). The respondents were requested to evaluate their ability to speak and read on a scale ranging from 1 (very poor) to 5 (like a native speaker), i.e., two entries. They were then asked to choose the number which best expressed their ability to perform certain activities in a foreign language (their best foreign language), such as understanding newspaper headlines, reading popular fiction without using a dictionary, and so on. In total, they were asked to comment on nine entries. Cronbach's alpha for this language proficiency measuring tool equals 0.956 . Each listing is highly correlated, and the instrument used in the research is reliable.

The questionnaire was sent to 243 students in the English language bachelor's program at the University of Finance and Administration. $43 \%$ of the questionnaires were returned. The most numerous group by nationality consisted of students from China. After removing any missing or otherwise defective responses (i.e., those which were found to have had zero or overly low determinative deviation in the case of $C Q$ ), the responses from 91 respondents were analyzed, of which 35 were men and 56 were women. The respondents were divided into two groups to test the $\mathrm{H} 2$ hypothesis. The first consisted of 35 bilingual respondents, while the second included the remaining 56 monolingual respondents, i.e., those who did not acquire an average language proficiency value over 4.22 in the questionnaire.

The authors are aware of several limitations and limits which could have distorted the submitted conclusions and results. The respondents evaluated their level of language proficiency by means of a subjective assessment. It would have been possible to acquire a more precise indicator of their level of skill by using standardized international language tests such as TOEFL, for example (Prucha, 2010). The 
boundary for the advanced knowledge of a foreign language was set somewhat arbitrarily. Luna et al. (2008) considered all their respondents who achieved a value of 4 in their evaluation of the language proficiency in a foreign (non-native) language to be bilingual. In this regard, even stricter criteria were adopted: only those who achieved a declared average result at a level of 4.22 and above in the language proficiency questionnaire belonged to the bilingual group.

Nevertheless, it is possible that different limits for this boundary would also lead to different results. Last but not least, it is a fact that the sample of the study is relatively small. This could also have distorted the results and findings of the study, even though the used PLS-SEM data analysis approach has been adapted to work with a relatively small sample of respondents. Its objective is to examine the relationships between certain latent variables or the predictive ability of the proposed theoretical model. The relatively small number of respondents and the novelty of the relationship proposed in this study have been justified by the use of PLS-SEM. However, it is still true that the results will be increasingly more precise as the number of respondents grows. Therefore, the conclusions of this study will be tested and verified using another (unconventional) sample with a more significant number of respondents. However, different analytical tool is suited to this purpose, namely CB-SEM.

Results. The measurement model is set out in Table 1. Several entries were omitted (COG1, COG2, COG4, COG5, COG6, BEH1-5) in line with the stated recommendation (Garson, 2016) because of the values of their loadings were less than 0.7 . This meant that the indicators of some parameters (such as AVE, for example) improved in the model. It is apparent from Table 1 that only two entries in the cognitive component of $C Q$ failed to exceed the value of 0.7 (the designated criteria). Nevertheless, according to Haira et al. (2016), it is still possible to work with all entries within the range of 0.4-0.7, i.e., it is not necessary to delete and cancel them if the AVE indicator is in order, i.e., greater than 0.5 (Sharma, 2019).

Table 1. The measurement model

\begin{tabular}{|c|c|c|}
\hline Latent variables and indicators & $\begin{array}{l}\text { Factor } \\
\text { loading }\end{array}$ & $\begin{array}{l}\text { External } \\
\text { VIF }\end{array}$ \\
\hline $\begin{array}{l}\text { CQ (a 0,905, rho_A 0,911, pc 0,922, AVE 0,543) } \\
\text { Agreement or disagreement with the following statements } \\
\text { using a 7-point scale: } 1=\text { strongly disagree, } 7=\text { strongly agree } \\
\text { 1. I am conscious of the cultural knowledge I use when interacting with different } \\
\text { cultural backgrounds. } \\
\text { 2. I adjust my cultural knowledge as I interact with people from a culture that is } \\
\text { unfamiliar to me. }\end{array}$ & 0.701 & $\begin{array}{l}2.221 \\
3.296\end{array}$ \\
\hline $\begin{array}{l}\text { 3. I am conscious of the cultural knowledge which I apply to cross-cultural interactions. } \\
\text { 4. I check the accuracy of my cultural knowledge as I interact with people from different } \\
\text { cultures. } \\
5 \text {. I know the cultural values and religious beliefs of other cultures. } \\
\text { 8. I enjoy interacting with people from different cultures. }\end{array}$ & $\begin{array}{l}0.771 \\
0.686 \\
0.607 \\
0.749\end{array}$ & $\begin{array}{l}3.756 \\
1.943 \\
1.664 \\
2.660\end{array}$ \\
\hline $\begin{array}{l}\text { 9. I am confident that I can socialise with locals in a culture that is unfamiliar to me. } \\
\text { 10. I am sure I can deal with the stresses of adjusting to a culture that is new to me. }\end{array}$ & $\begin{array}{l}0.822 \\
0.743\end{array}$ & $\begin{array}{l}3.501 \\
2.190\end{array}$ \\
\hline $\begin{array}{l}\text { 11. I enjoy living in cultures that are unfamiliar to me. } \\
\text { 12. I am confident that I can get used to the shopping conditions in a different culture. }\end{array}$ & $\begin{array}{l}0.663 \\
0.775\end{array}$ & $\begin{array}{l}1.767 \\
2.100\end{array}$ \\
\hline
\end{tabular}


Continued Table 1

\begin{tabular}{llc}
\hline Listening & 0.811 & 2.899 \\
Speaking & 0.776 & 2.300 \\
The ability to perform tasks in your best foreign language. & & \\
Using a 5-point scale: 1 = very poor, 5 = very good & & \\
$\begin{array}{l}\text { 1. Understanding cooking instructions, such as those in a recipe. } \\
\text { 2. Understanding newspaper headlines. }\end{array}$ & 0.829 & 3.403 \\
3. Reading personal letters or notes written to you. & 0.804 & 3.106 \\
4. Reading popular novels without using a dictionary. & 0.852 & 3.580 \\
5. Making a shopping list. & 0.753 & 2.331 \\
6. Filling out a job application form that requires information about your interests and & 0.892 & 4.744 \\
qualifications. & 0,872 & 4,017 \\
7. Writing a letter to a friend. & 0,861 & 3,933 \\
8. Leaving a note for someone explaining where you will be or when you will come home. & 0,875 & 4,669 \\
9. Writing an advertisement to sell a bicycle. & 0,845 & 3,297 \\
\hline
\end{tabular}

Notes: $\alpha=$ Cronbach's alpha, $\mathrm{Pc}=$ composite reliability, $\mathrm{AVE}=$ Average variance extracted, $\mathrm{CQ}=$ cultural intelligence Removed entries (the entry indicators were below the value of 0.7): COG1, COG2, COG4, COG5, COG6, BEH1-5. The loadings of all entries $>0.5$ points to the reliability of the indicators All AVE (Average Variance Extracted) $>0.5$, which points to the convergent reliability (Fornell and Larcker, 1981). All of the values of the composite reliability $(C R)>0.7$, which points to their internal consistency (Sharma, 2019). All values of Cronbach's alpha $>0.7$, which points to the reliability of the indicators.

Sources: developed by the authors.

The Fornell-Larcker criterion has been used to show that the constructs are unique and that they differ from one another. In other words, the result of the root of the AVE for each construct (i.e., CQ and language proficiency) is higher than the correlation between both constructs. The HTMT (Heterotrait-Monotrait Ratio) of our model for two constructs is equal to 0.487 . Given that this value is less than 0.9 , and the reliability interval for the model does not include 1 , the discriminant validity of the constructs has been confirmed (Kline, 2011). All of the indicators of the VIF (variance inflated factor) are less than 5 (see Table 1), which means that our model does not suffer from multicollinearity (Hair Jr et al., 2017). The conformity of the data with the model does not fully meet the set criteria (RMS_theta $=0.171$; SRMR $=0.065$ and NFI $=0.770$ ), but, unlike in CB-SEM, data conformity does not play such a fundamental role in PLS-SEM (Hair et al., 2019).

Table 2 summarises the results of the differences between the two groups (MGA-PLS). The results are statistically significant, with a $5 \%$ margin of statistical error, if the $p$ values are smaller than 0.05 and more substantial than 0.95 for the path coefficient differences in the specific groups. At the same time, the table sets out the results of the parametric test based on the presumption of the equal distribution in all groups and the Welch-Satterthwaite test, which works with the assumption of non-homogenous data distribution in all the groups (Hair Jr et al., 2017). 
Table 2. The language proficiency and $C Q$ relationship between two effects (bilingual vs monolingual)

\begin{tabular}{|c|c|c|c|c|c|c|c|c|c|}
\hline Hyp. & Relationship & $\begin{array}{l}\text { Std. } \\
\text { Beta }\end{array}$ & St. dev. & t- value & ROZ & $\begin{array}{l}95 \% \\
\text { CI LL } \\
\end{array}$ & $\begin{array}{l}95 \% \\
\text { CIUL } \\
\end{array}$ & $\begin{array}{c}\begin{array}{c}\text { Parametric } \\
\text { test }\end{array} \\
\text { p-values }\end{array}$ & $\begin{array}{c}\text { Welch - } \\
\text { Satterthwaite } \\
\text { test } \\
\text { p-values }\end{array}$ \\
\hline H1 & $\mathrm{PROF} \rightarrow \mathrm{CQ}$ & 0.495 & 0.086 & $5.378^{\star \star}$ & YES & 0.359 & 0.646 & & \\
\hline \multicolumn{10}{|c|}{ Bilingual ( $N=35)$} \\
\hline $\mathrm{H} 2$ & $\mathrm{PROF} \rightarrow \mathrm{CQ}$ & 0.028 & 0.613 & 0.859 & NO & -0.808 & 0.659 & 0.081 & 0.155 \\
\hline \multicolumn{10}{|c|}{ Monolingual $(\mathrm{N}=56)$} \\
\hline $\mathrm{H} 2$ & $\mathrm{PROF} \rightarrow \mathrm{CQ}$ & 0.451 & 0.148 & $2.535^{*}$ & YES & -0.69 & 0.447 & 0.081 & 0.155 \\
\hline
\end{tabular}

Source: developed by the authors.

Conclusions. According to a report published by the New American Economy (2017), the demand for multilingual workers more than doubled in the U.S. from 2010 to 2015. The examples of some bilingual countries such as Switzerland, Belgium, the Netherlands, Finland or Norway in which a relatively high number of citizens can fluently converse in languages other than their mother tongue show that these nations might have a strategic advantage in international business which is indirectly assumed by their high trade-to-GDP ratio (The World Bank Group, 2019). On the other hand, it cannot be stated that bilingual individuals (or those with high language proficiency in two languages) will automatically benefit from their bicultural identity; the intercultural benefit will occur if they are active in an area which is associated with the word which they can speak correctly or/and they are culturally intelligent.

This explorative study has taken the first look at cultural intelligence in bilingual individuals (i.e., in those who have a high level of proficiency in two languages). The analysis of the data has confirmed that a positive correlation relationship exists between both variables, i.e., language competence (language proficiency) predicates the overall score for $\mathrm{CQ}$. However, other facts were also ascertained in addition to this: two CQ components in particular (the metacognitive and motivational components) play a substantial role within the framework of this relationship.

Specifically, the first hypothesis $(\mathrm{H} 1)$, i.e., the existence of a relationship between the two variables (language proficiency and cultural intelligence), has been proven based on the analysis of the required data in concordance with other studies (Jyoti and Kour, 2017). If, however, we view this relationship from the two groups of respondents (bilingual and monolingual), the result is no longer so straightforward; the effect is only statistically significant for the monolingual group, but not for the bilingual group, which is surprising to a certain extent. No statistically significant difference was found between the two groups, as is shown by the values from the parametric and Welch-Satterthwaite tests in Table 2. Hypothesis $2(\mathrm{H} 2)$ was not confirmed.

Our analysis pointed to several possible problems. For the concurrent criterion to be met (AVE $>0.5$ is an acceptable value and means that the construct explains at least a $50 \%$ dispersion of its entries), almost all of the listings about the behavioral and cognitive elements of $C Q$ would have had to have been omitted from the $C Q$ construct. Our study mainly deals with $C Q$ in general (and not its components) about the bilingual knowledge of two languages. Nevertheless, it is also possible to reach several subconclusions concerning the individual dimensions of $\mathrm{CQ}$. Given that an individual who can speak several languages fluently will be better able to obtain and acquire (for example, through contact with local people) important information about a foreign culture (in the sense of its values, norms, customs and so on), it can be expected that $C Q$ will positively correlate to the knowledge of languages. Previous studies (Eisenberg 
et al., 2013; Shannon and Begley, 2008) have confirmed this relationship most frequently. In the case of the present study, however, it is not possible to presuppose any significant development in the cognitive component of $C Q$ due to linguistic knowledge via intensive contact with the citizens of the host country, because the research respondents were foreigners (mostly with a very limited amount of Czech) studying at a Czech university in English, i.e. in a non-native language. As such, it is possible to also reach the same conclusion about the behavioral component of $\mathrm{CQ}$ : given that the respondents are significantly limited in their contact with the local people due to their lack of knowledge of the language of the host country, their verbal (and non-verbal) expression is not relevant to the Czech cultural environment and as such, the behavioral component of $C Q$ need not correlate with their language proficiency.

On the other hand, the connection between the linguistic level and the motivational component of $C Q$ is easily understandable. Individuals with a high motivational $C Q$ are convinced that they will be successful in a new cultural environment; such individuals anticipate that conflict situations of an intercultural nature will occur sooner or later. They do not doubt that the cultural experience is enriching and meaningful for them, that it helps them develop internally, and it fulfills them. As such, they are prepared and motivated to face any future problems. They are not afraid of the unknown. They actively seek out new cultural experiences. They are not dissuaded by any unpleasant or embarrassing experiences.

Given that the source of cultural learning is people who are its bearers, have grown up in it, and have been formed by it, a person with a high motivational $C Q$ likes spending time in their company and speaking with them. Such people are aware of the fact that a good knowledge of the language in question is necessary for them to be able to socialize in the new culture. Therefore, they are highly motivated to study the language in question. They are aware of the fact that the more they can speak the language of the given cultural environment, the closer they will be able to get to foreigners. That is why the motivational component of $\mathrm{CQ}$ is associated with language proficiency.

The result of this study substantially conforms with the conclusions of other studies (L. Cohen and Kassis-Henderson, 2017), in which the authors cast doubt on the mainstream assumptions of language proficiency: the native speaker as the paradigm for studying foreign languages. They have shown that excellent knowledge of a given language may be less relevant and significant than the metacognitive skills acquired through contact (for example, in the workplace) with multiple styles and cultural approaches. The importance of international experience for effective functioning in a new cultural environment has also been confirmed by other research (for example, Collins, Duyar, and Pearson, 2016).

Knowledge of the dominant foreign language of the environment (work or otherwise) in which the person spends most of their time is essential, but the significance of this relationship need not be overstated, as has also been shown by the value of the $\mathrm{f}^{2}$ effect $(=0.270)$ of the influence of language proficiency on CQ. According to Cohen's criteria (J. Cohen, 1988), the strength of this relationship is rated as medium. In other words, there are also variables other than language proficiency (such as the aforementioned international experience, long-term work or study stays abroad, and so on, for example), which have an impact on $C Q$.

However, examining the relationship between language proficiency and $C Q$ in the two separate groups, i.e., the bilingual group, which spoke two languages (including its native language) at a very high level and the monolingual group, a surprising fact has been found. This relationship was statistically significant in the monolingual group, but not in the bilingual group. This can be explained by the fact that cultural intelligence constitutes a specific disposition towards successful functioning in a foreign, unknown cultural environment, while biculturalism (often mixed with bilingualism) is a particular trait of personality; the identity of the bilingual individual transforms using the CFS mechanism (S. Chen and Bond, 2010; Luna, Ringberg, and A. Peracchio, 2008; Veltkamp et al., 2013).

If one of two cultural circuits is activated (the trigger may be language or certain cultural symbols), a bilingual individual starts to behave in the mode of the given culture. Biculturalism manifests itself in the 
dual uniqueness of monolingual individuals who act as monolingual individuals in certain situations and given moments. Biculturalism (induced by the switching between two correctly spoken languages) is a specific permanent personality trait that influences the dynamics of a person's experiences and behavior. On the other hand, cultural intelligence is a particular ability that constitutes a prerequisite for functioning successfully in a different cultural environment. It is an indicator of the differences in the quality, speed, and ease of adopting certain rules, customs, and ways of conduct in interaction with an unknown cultural context. In the case of bilingual and bicultural individuals, this often involves an unconscious process, while this is a fully conscious process in the case of a monocultural individual with a high CQ; perhaps, for this reason, language proficiency played a role in the second (but not in the first, bilingual) group.

One explanation for these surprising results in the study may reside in the definition of bilingual individuals. For example, Pavlenko (2006) considered everybody who uses two languages in their daily life to be bilingual regardless of the level of the used words. Given that the majority of the respondents ( $n$ $=83$ ) declared that they use two languages in their current lives, all of these respondents are bilingual by Pavlenko's definition (2006) and it is not necessary to ascertain the level (in the sense of their proficiency) of their linguistic knowledge. The division of the respondents into bilingual and monolingual groups would, therefore, lose its meaning (or its justification), and as such, no difference could have been found between the groups.

Last but not least, it is also worth considering the results of the study (Ott and Michailova, 2017), in which the authors discovered that the most significant contribution is made to the development of $C Q$ during international (in this case study) stays if students attend courses not only in English (as the given lingua franca for tertiary education), but also in the official language of the university. A mix of both languages is ideal in this regard rather than lessons being held exclusively in one or a second language throughout the semester when students are at the university.

The stated limits of this study have opened up opportunities for further research. Also, it is possible to examine the cultural intelligence of bilingual individuals who speak and communicate in the language of their parents (immigrants) within the framework of their community, but at the same time talk about the language of their host country entirely thanks to the education process which they have undergone (for example, the Vietnamese minority in the Czech Republic). The research to date, which has dealt with the relationship between cultural intelligence and language proficiency (measured by the number and level of the spoken languages), has focused on language proficiency in the general sense of the word and knowledge of the language of the host country. Other researchers could examine this relationship in an application for specific languages, such as Esperanto, for example.

Author Contributions: conceptualization, M. J.; methodology, M. J.; software, M. J.; validation, M. J.; formal analysis, M. J.; investigation, M. J.; resources, T. P.; data curation, M. J.; writing-original draft preparation, M. J.; writing-review and editing, T.P.; supervision, M. J.; project administration, M. J.; funding acquisition, M. J. and T. P.

Funding: The result has been created under the «Cultural and Psychological Aspects of Bilingualism» junior project with institutional support for the long-term conceptual development of the research from the University of Finance and Administration.

\section{References}

Andresen, M., \& Bergdolt, F. (2017). A systematic literature review on the definitions of global mindset and cultural intelligencemerging two different research streams. The International Journal of Human Resource Management, 28(1), 170-195. [GoogleScholar] [CrossRef]

Ang, S., \& Van Dyne, L. (2015). Conceptualization of cultural intelligence: Definition, distinctiveness, and nomological network. In Handbook of cultural intelligence (pp. 21-33). Routledge. 


\section{M., Jurasek, T., Potocky. Management of Innovations in Cross-Cultural Communication within an Organization}

Ang, S., Van Dyne, L., Koh, C., Ng, K. Y., Templer, K. J., Tay, C., \& Chandrasekar, N. A. (2007). Cultural intelligence: Its measurement and effects on cultural judgment and decision making, cultural adaptation and task performance. Management and Organization Review, 3(3), 335-371. [GoogleScholar] [CrossRef]

Barner-Rasmussen, W., Ehrnrooth, M., Koveshnikov, A., \& Makela, K. (2014). Cultural and language skills as resources for boundary spanning within the MNC. Journal of International Business Studies, 45(7), 886. [GoogleScholar] [CrossRef]

Bialystok, E., Craik, F. I. M., Green, D. W., \& Gollan, T. H. (2009). Bilingual Minds. Psychological Science in the Public Interest, 10(3), 89-129. [GoogleScholar] [CrossRef]

Boroditsky, L. (2011). How language shapes thought. Scientific American, 304(2), 62-65. [GoogleScholar]

Boski, P., \& Youssef, K. I. (2012). Consequences of linguistic frame switching: Cognitive and motivational shifts in bilingual Tunisians. Psychology of Language and Communication, 16(2), 143-163. [GoogleScholar] [CrossRef]

Brannen, M. Y., Piekkari, R., \& Tietze, S. (2017). The multifaceted role of language in international business: Unpacking the forms, functions and features of a critical challenge to MNC theory and performance. In Language in international business (pp. 139162). Springer. [GoogleScholar] [CrossRef]

Capatina, A., Micu, A., Lukacs, E., Micu, A. E., Cristache, N., \& Susanu, I. (2011). Opportunities for a Romanian company's business development in countries with cultural intelligence compatibility. African Journal of Business Management, 5(30), 1194611954. [GoogleScholar] [CrossRef]

Chen, A. S. Y., Lin, Y. C., \& Sawangpattanakul, A. (2011). The relationship between cultural intelligence and performance with the mediating effect of culture shock: A case from Philippine laborers in Taiwan. International Journal of Intercultural Relations, 35(2), 246-258. [GoogleScholar] [CrossRef]

Chen, S. X. (2015). Toward a social psychology of bilingualism and biculturalism. Asian Journal of Social Psychology, 18(1), 111. [GoogleScholar] [CrossRef]

Chen, S. X., Benet-Martinez, V., \& Harris Bond, M. (2008). Bicultural Identity, Bilingualism, and Psychological Adjustment in Multicultural Societies: Immigration-Based and Globalization-Based Acculturation. Journal of Personality, 76(4), 803-838. [GoogleScholar] [CrossRef]

Chen, S. X., Lam, B. C., Buchtel, E. E., \& Bond, M. H. (2014). The conscientiousness paradox: Cultural mindset shapes competence perception. European Journal of Personality, 28(5), 425-436. [GoogleScholar][CrossRef]

Chen, S., \& Bond, M. (2010). Two Languages, Two Personalities? Examining Language Effects on the Expression of Personality in a Bilingual Context. Personality \& Social Psychology Bulletin, 36, 1514-1528. [GoogleScholar] [CrossRef]

Cohen, J. (1988). Statistical power analysis for the behaviors science. (2nd). New Jersey: Laurence Erlbaum Associates, Publishers, Hillsdale.

Cohen, L., \& Kassis-Henderson, J. (2017). Revisiting culture and language in global management teams: Toward a multilingual turn. International Journal of Cross-Cultural Management, 17(1), 7-22. [GoogleScholar] [CrossRef]

Collins, K. S., Duyar, I., \& Pearson, C. L. (2016). Does cultural intelligence matter? Effects of principal and teacher cultural intelligence on Latino student achievement. Journal for Multicultural Education, 10(4), 465-488. [GoogleScholar] [CrossRef]

Crowne, K. A. (2009). The relationships among social intelligence, emotional intelligence and cultural intelligence. Organization Management Journal, 6(3), 148-163. [GoogleScholar]

Earley, P. C., \& Ang, S. (2003). Cultural intelligence: Individual interactions across cultures. Stanford University Press. [GoogleScholar]

Earley, P. C., Ang, S., \& Tan, J. S. (2006). CQ: Developing cultural intelligence at work. Stanford University Press

[GoogleScholar]

Eisenberg, J., Lee, H. J., Brueck, F., Brenner, B., Claes, M. T., Mironski, J., \& Bell, R. (2013). Can Business Schools Make Students Culturally Competent? Effects of Cross-Cultural Management Courses on Cultural Intelligence. Academy of Management Learning \& Education, 12(4), 603-621. [GoogleScholar] [CrossRef]

Fornell, C., \& Larcker, D. F. (1981). Evaluating structural equation models with unobservable variables and measurement error. Journal of Marketing Research, 18(1), 39-50. [GoogleScholar] [CrossRef]

Gabel-Shemueli, R., Westman, M., Chen, S., \& Bahamonde, D. (2019). Does cultural intelligence increase work engagement? The role of idiocentrism-allocentrism and organizational culture in MNCs. Cross Cultural \& Strategic Management; Bingley, 26(1), 46-66. [GoogleScholar] [CrossRef]

Garson, G. D. (2016). Partial least squares: Regression and structural equation models. Asheboro, NC: Statistical Associates Publishers.

Grosjean, F. (2015). Bicultural bilinguals. International Journal of Bilingualism, 19(5), 572-586. [GoogleScholar] [CrossRef]

Hair Jr, J. F., Hult, G. T. M., Ringle, C., \& Sarstedt, M. (2016). A primer on partial least squares structural equation modeling

(PLS-SEM). Sage publication. [GoogleScholar]

Hair Jr, J. F., Sarstedt, M., Ringle, C. M., \& Gudergan, S. P. (2017). Advanced issues in partial least squares structural equation modeling. Sage Publications. [GoogleScholar]

Hair Jr, J. F., Sarstedt, M., Ringle, C. M., \& Gudergan, S. P. (2017). Advanced issues in partial least squares structural equation modeling. Sage publications. [Google Scholar]

Hair, J. F., Risher, J. J., Sarstedt, M., \& Ringle, C. M. (2019). When to use and how to report the results of PLS-SEM. European Business Review, 31(1), 2-24. [GoogleScholar] [CrossRef] 


\section{M., Jurasek, T., Potocky. Management of Innovations in Cross-Cultural Communication within an Organization}

Henseler, J., Dijkstra, T. K., Sarstedt, M., Ringle, C. M., Diamantopoulos, A., Straub, D. W., Calantone, R. J. (2014). Common beliefs and reality about PLS: Comments on Ronkko and Evermann (2013). Organizational Research Methods, 17(2), 182-209. [GoogleScholar] [CrossRef]

Hensler, J., Ringle, C. M., \& Sarstedt, M. (2015). A new criterion for assessing discriminant validity in variance-based structural equation modeling. Journal of the Academy of Marketing Science, 43(1), 115-135. [GoogleScholar] [CrossRef]

Hofstede, G., Hofstede, G. J., \& Minkov, M. (2010). Cultures and Organizations: Software of the Mind. Revised and expanded (3rd Edition). $\quad$ New $\quad$ York.: McGraw-Hill. $\quad$ Retrieved from https://eedu.nbu.bg/pluginfile.php/900222/mod_resource/content/1/G.Hofstede_G.J.Hofstede_M.Minkov $\% 20 \% 20$ Cultures $\% 2 a n d \%$ 200rganizations $\% 20-\% 20$ Software $\% 20$ of $\% 20$ the $\% 20$ Mind $\% 203 \mathrm{rd}$ edition $\% 202010$.pdf

Huff, K. C. (2013). Language, cultural intelligence and expatriate success. Management Research Review, 36(6), 596-612. [GoogleScholar] [CrossRef]

Jyoti, J., \& Kour, S. (2017). Factors affecting cultural intelligence and its impact on job performance: Role of cross-cultural adjustment, experience and perceived social support. Personnel Review; Farnborough, 46(4), 767-791. [GoogleScholar] [CrossRef] Kaufman, S. R., \& Hwang, A. (2015). Cultural intelligence and mindfulness in two French banks operating in the US environment. Management Research Review, 38 (9), 930-51. [GoogleScholar] [CrossRef]

Kline, R. B. (2011). Principles and practice of structural equation. Modeling. (3nd).

Kmiotek, L. (2017). Language Proficiency and Cultural Identity as Two Facets of the Acculturation Process. Psychology of Language and Communication, 21(1), 192-214. [GoogleScholar] [CrossRef]

Luna, D., Ringberg, T., \& Peracchio, L. A. (2008). One Individual, Two Identities: Frame Switching among Biculturals. Journal of Consumer Research, 35, 279-293. [GoogleScholar] [CrossRef]

New American Economy (2017). Not Lost in Translation: The Growing Importance of Foreign Language Skills in the US Job Market. Retrieved from http://www.newamericaneconomy.org/wp-content/uploads/2017/03/NAE Bilingual V8.pdf

Oliver, E., de Botton, L., Soler, M., \& Merrill, B. (2011). Cultural Intelligence to Overcome Educational Exclusion. Qualitative Inquiry, 17(3), 267-276. [GoogleScholar] [CrossRef]

Ott, D. L., \& Michailova, S. (2017). Does exposure to host country language during international experiences influence the development of cultural intelligence? European Journal of International Management, 11(6), 733-753. [GoogleScholar] [CrossRef] Pavlenko, A. (2006). Bilingual selves. Bilingual Education and Bilingualism, 56, 1. [GoogleScholar]

Petru, N., Tomaskova, A. \& Kroslakova, M. (2019). Diversification of Export Territories of Family Businesses as a Tool of their Futher Development. Problems and Perspectives in Management, 17(3), 306-322. [GoogleScholar] [CrossRef]

Presbitero, A., \& Attar, H. (2018). Intercultural communication effectiveness, cultural intelligence and knowledge sharing: Extending anxiety-uncertainty management theory. International Journal of Intercultural Relations, 67, 35-43. [GoogleScholar] [CrossRef]

Prucha, J. (2010). Interkulturni komunikace. Grada Publishing as. [Google Scholar]

Putranto, N. A. R., Nuraeni, S., Gustomo, S. \& Ghazali, A. (2018). The Relationship between Cultural Intelligence, Emotional Intelligence, and Student Performance," International Journal of Business, 23 (1), 17-25. [GoogleScholar]

Schreuders-van den Bergh, R. \& Du Plessis, Y. (2016). Exploring the role of motivational cultural intelligence in SIE women's adjustment. Journal of Global Mobility-the Home of Expatriate Management Research, 4 (2), 131-48. [GoogleScholar] [CrossRef]

Shannon, L. M., \& Begley, T. M. (2008). Antecedents of four-factor model of cultural intelligence. Handbook of cultural intelligence: Theory, measurement, and application, 41-55. [GoogleScholar]

Sharma, R. R. (2019). Cultural Intelligence and Institutional Success: The Mediating Role of Relationship Quality. Journal of International Management, 25(3), 1006-65. [GoogleScholar] [CrossRef]

The World Bank Group (2019). The World Bank Data Report on Trade (\% of GDP). Retrieved from https://data.worldbank.org/indicator/NE.TRD.GNFS.ZS

Thomas, D. C., Elron, E., Stahl, G., Ekelund, B. Z., Ravlin, E. C., Cerdin, J. L. and Lazarova, M. B. (2008). Cultural Intelligence: Domain and Assessment. International Journal of Cross/Cultural Management, 8(2), 123-143. [GoogleScholar] [CrossRef]

Van Dyne, L., Ang, S., \& Tan, M. L. (2016). Cultural intelligence. [GoogleScholar] [CrossRef]

Van Dyne, L., Ang, S., Ng, K. Y., Rockstuhl, T., Tan, M. L., \& Koh, C. (2012). Sub-dimensions of the four factor model of cultural intelligence: Expanding the conceptualization and measurement of cultural intelligence. Social and Personality Psychology Compass, 6(4), 295-313. [GoogleScholar] [CrossRef]

van Oudenhoven, J. P., \& Benet-Martínez, V. (2015). In search of a cultural home: From acculturation to frame-switching and intercultural competencies. International Journal of Intercultural Relations, 46, 47-54. [GoogleScholar] [CrossRef]

Veltkamp, G. M., Recio, G., Jacobs, A. M., \& Conrad, M. (2013). Is personality modulated by language? The International Journal of Bilingualism; London, 17(4), 496-504. [GoogleScholar] [CrossRef] 
Мирослав Юрасек,

Ph.D., Університет фінансів та управління, Чеська республіка

Томіслав Потоцький,

Ph.D., Університет фінансів та управління, Чеська республіка

Управління інноваціями в кроскультурному середовищі організаціі

У даній статті систематизовано аргументи та контраргументи у рамках наукової дискусії щодо взаємозв'язку між мовною та культурною компетентностями працівників, як однієї з умов їх ефектиивної профресійної діяльності. Обгрунтовано сучасні тенденції у кадровому забезпеченні підприємств, визначено проблеми та пріоритетний вплив мовною та культурною компетентностями працівників на результати діяльності; зміну ціннісних орієнтирів у системі менеджменту підприємств. Основною метою проведеного дослідження є визначення взаємозв'язку між білінгвізмом (володіння двома іноземними мовами на високому рівні) та культурною компетентністю працівників, як необхідної умови забезпечення конкурентоспроможності організації. Вирішення поставлених в роботі завдань здійснено в наступній логічній послідовності: 1) проведення теоретичного аналізу концептуальних засад управління інноваціями в кроскультурному середовищі організації; 2) формування гіпотез дослідження; 3) опис відповідної методології дослідження; 4) встановлення взаємозв'язку між культурною та мовною компетентностями працівників. Об'єктом дослідження обрано 243 студенти освітнього ступеню бакалавр, які вивчали англійську мову в Чеському університеті фінансів та адміністрації. Емпіричне підтвердження висунутої в роботі гіпотези про статистично значимий взаємозв'язок між культурною та мовною компетентностями працівників здійснено за допомогою програмного забезпечення SmartPLS-SEM 3. Отримані результати дослідження емпірично підтверджують та теоретично доводять наявність позитивної кореляції між рівнем володіння іноземною мовою та рівнем культурного капіталу. Зазначено, що мовна компетентність визначає загальну оцінку культурного капіталу. Встановлено, що метакогнітивні та мотиваційні фрактори культурного капіталу мають статистично значимий вплив та визначають характер взаємозв'язку між володінням іноземною мовою та рівнем культурного капіталу. В статті представлено результати емпіричного аналізу, який засвідчив статистично значущу різницю між групами білінгвістів та монолінгвістів. Результати дослідження мають практичне значення і можуть бути прийняті до впровадження менеджерами, які працюють в кроскультурному середовищі, здійснюють підготовку студентів до роботи за кордоном або в міжнародних командах.

Ключові слова: культурна компетентність, мовна компетентність, білінгвізм, культурна комунікація кадрів, PLS-SEM, ефективність міжкультурної взаємодії

Manuscript received: 26.09.2019

(C) The author(s) 2020. This article is published with open access at Sumy State University. 